\title{
An improved procedure for in vivo and in vitro propagation of Buxus hyrcana, an ornamental shrub critically at risk of extinction
}

\author{
NaSer Negahdar, Davood Hashemabadi * BehZad KaViani \\ Department of Horticultural Science, Rasht Branch, Islamic Azad University, Rasht, Iran
}

\begin{abstract}
The ornamental shrub, Buxus hyrcana is a threatened species due to the attacks of some pathogens. Rooting of this valuable shrub using propagation techniques such as cuttings is very slow. The present study was carried out to evaluate the effect of different concentrations of indole-3-butyric acid (IBA) and kinetin (KIN) on rooting of semi-hardwood cuttings and in vitro propagation of B. hyrcana. In propagation experiment, the basal region of the cuttings was treated with IBA and KIN solutions $(0.00,500,1000$ and $2000 \mathrm{mg} / \mathrm{l}$ of each). The cuttings were then transferred to rooting beds filled with perlite. After a rooting period of 60 days, some morphological parameters were measured. The $500 \mathrm{mg} / \mathrm{KIN}$ along with $1000 \mathrm{mg} / \mathrm{lBA}$ induced the largest number of roots (16.80 per plantlet). A maximum of $8.16 \mathrm{~cm}$ root length per plantlet was obtained with $1000 \mathrm{mg} / \mathrm{lBA}$ together with $1000 \mathrm{mg} / \mathrm{l} \mathrm{KIN}$. The largest number of leaves (105.00) was observed in rooted stem cuttings treated with $2000 \mathrm{mg} / \mathrm{l} \mathrm{IBA}$ along with $1000 \mathrm{mg} / \mathrm{l} \mathrm{KIN}$. In tissue culture experiment, the medium enriched with $2.00 \mathrm{mg} / 1 \mathrm{KIN}$ together with $0.50 \mathrm{mg} / \mathrm{l} \mathrm{IBA}$ was found to be suitable for obtaining the maximum leaf number (11.43 per explant). A higher rooting frequency was also observed with the highest rooting of 6.50 roots per cutting achieved in plantlets grown in a medium supplemented with $\mathrm{KIN}$ and IBA $(1.00 \mathrm{mg} / \mathrm{l}$ each). In vitro rooted plantlets were cultivated in plastic pots containing peat and perlite (in ratio of $1: 1$ ). The plantlets were successfully acclimatized in an adaptation greenhouse with a survival rate of $95 \%$ exhibiting normal developmental patterns.
\end{abstract}

Key words: endangered plants, ornamentals, plant growth regulators, rooting, stem cutting, tissue culture

\section{Introduction}

Buxus from the family Buxaceae is a genus containing about 70 species of evergreen shrubs and trees found in habitats ranging from rocky hills to woodlands in Europe, Asia, Africa and Central America. Common boxwood (Buxus hyrcana or Buxus sempervirens) is a bushy, rounded shrub or small tree with ovate to oblong, glossy and dark green leaves. Boxwoods are grown mainly for their foliage, which may be variegated (Brickell and Zuk, 1996). This species is in danger of extinction due to the invasion with some pathogens.

Propagation of boxwood is done by seeds and cuttings. Seeds propagation is a slow process; it is time consuming and results in heterogeneous plants with segregation of traits. Vegetative propagation is an alternative method for conservation of endangered plants threatened with extinction; it also helps to maintain certain desired characteristics in the plants (Hartmann et al., 2002). Roots produced in the cultures in vitro through the use of plant growth regulators (PGRs) are stronger and emerge faster and more in number than those produced without application of PGRs (Sağlam et al., 2014). The formation of root primordium cells depends on the presence of endogenous auxins in the cutting area or on application of exogenous auxins. Adventitious root formation in cuttings is an important process for vegetative propagation of many plant species, especially hard- and semi-hard wood cuttings of trees and shrubs (Husen et al., 2015; Kaviani and Negahdar, 2017).

\footnotetext{
* Corresponding author: Department of Horticultural Science, Rasht Branch, Islamic Azad University, Rasht, Iran; e-mail: davoodhashemabadi@yahoo.com
} 
The success of vegetative reproduction depends on the interaction of hereditary factors and some biological and external factors particularly PGRs (de Oliveira et al., 2003; Davidović et al., 2015). The application of exogenous PGRs, especially the auxins group, can increase the success of adventitious rooting in the stem; IBA is the most commonly used auxin (Hartmann et al., 1997; Brondani et al., 2012; Davidović et al., 2015; Kaviani and Negahdar, 2017). Rooting of tree species through stem cuttings is affected by several factors particularly cultivation beds and PGRs (Hartmann et al., 2002). Application of auxins, especially IBA and $\alpha$-naphthaleneacetic (NAA) is recommended for production of adventitious roots in stem-cutting propagation of many shrubs and trees (Hartmann et al., 2002; Hunt et al., 2011; Husen et al., 2015; Kaviani and Negahdar, 2017). Tsipouridis et al. (2003) demonstrated that IBA at $2000 \mathrm{mg} / \mathrm{l}$ concentration stimulated rooting of hardwood and semi-hardwood cuttings of peach trees (Prunus persica (L.) Batch). Hartmann et al. (1997) revealed that the application of IBA at 2500 to $4000 \mathrm{mg} / \mathrm{l}$ concentration had the best results in rooting of the semi-hardwood cuttings of apple, plum, and olive. The positive effect of $3000-4000 \mathrm{mg} / \mathrm{l}$ auxin in increasing rooting the cuttings of woody ornamental shrubs such as roses and Chinese hollyhock has been demonstrated (Al-Sagri and Alderson, 1996). Usually, a concentration of $2000-4000 \mathrm{mg} / \mathrm{l}$ will result in a proper rooting for most shrubs and evergreens (Poston, 2007).

The application of biotechnology and tissue culture in particular, is an appropriate method for reproduction of rare and threatened plants that are difficult to propagate. This method is becoming increasingly important for propagation and preservation of rare and endangered plant species (Kaviani and Negahdar, 2017). Plant tissue culture and micropropagation techniques also play an important role in preservation programs and management of botanical collections (Mahendran and Bai, 2009). Kaviani and Negahdar (2017) reported that the maximum in vitro multiple shoot formation in B. hyrcana was obtained through the use of $1.00 \mathrm{mg} / 16$-benzylaminopurine (BAP). The optimum PGR combination for the largest number of roots was found to be $0.50 \mathrm{mg} / \mathrm{l} \mathrm{BAP}$ and $1.00 \mathrm{mg} / 1 \mathrm{NAA}$. There are very few reports regarding propagation of $B$. hyrcana through the rooting of semi-hardwood stem cuttings. Furthermore, the only reference found regarding the in vitro propagation of this species was the previous study by the present group on B. hyrcana (Kaviani and Negahdar, 2017). Therefore, the objectives of this study were to 1) develop an effective protocol for root induction from hard-wood stem cuttings; and 2) to establish a reliable procedure for in vitro propagation of $B$. hyrcana, a threatened ornamental shrub.

\section{Materials and methods}

Boxwood (Buxus hyrcana Pojark.), an ornamental shrub species, was obtained from a commercial landscape and garden company in Mazandaran province, Iran. The acquired plants were used as mother plants. The mother plants were transported to the plant tissue culture laboratory located in the Hyrcan Agricultural Science and Biotechnology Research Institute, Amol, Iran.

\section{Experiment 1. In vivo propagation}

\section{Plant materials and treatments}

Stems collected from two-years-old plants grown in a greenhouse were used as the source of cuttings. Stem cuttings of $20 \mathrm{~cm}$ length with 16 leaves (Fig. 1A) were disinfected by immersion in silver Nano-particles at a concentration of $250 \mathrm{mg} / \mathrm{l}$ for $10 \mathrm{~s}$. To induce adventitious rooting, the basal region of the stem cuttings was dipped in solutions containing 0 (control, no IBA and KIN), 500, 1000 and $2000 \mathrm{mg} / \mathrm{l}$ of both IBA and KIN for $10 \mathrm{~s}$.

\section{Cultivation bed and growth conditions}

After the treatments, the cuttings were placed in pots filled with perlite. They were maintained in a greenhouse to induce rhizogenesis. Fertilization was not performed. Plastic pots $\left(70 \times 38 \times 4 \mathrm{~cm}^{3}\right)$ were used as the cultivation container (Fig. 1F). The temperature of greenhouse was adjusted to $24^{\circ} \mathrm{C}$ and the air relative humidity (RH) so that it exceeded $80 \%$.

\section{Measured parameters}

Evaluations were performed after a rooting period of 60 days. Plantlets height, stem diameter, shoot number, leaf number, node number, root length and root number were measured.

\section{Experimental design and statistical analysis}

A full factorial experiment in a completely randomized design was employed. Four replicates of five cut- 
tings were randomly assigned per treatment; thus, a total of 320 cuttings were used. All the statistical analyses were done by using Microsoft Excel 2013 and Statistical Package for Social Sciences (SPSS) v 16.0. The analysis of variance (ANOVA) procedure for factorial experiments was used to test for the significant effect of treatments, followed by least significant difference (LSD) test for comparisons of different means of different treatments.

\section{Experiment 2. In vitro micropropagation}

\section{Explant source and sterilization}

Shoot tips obtained from the mother plants was used as explants for the establishment of cultures. Shoots (4-5 cm long) were washed under running tap water for $60 \mathrm{~min}$. with a few drops of washing liquid. Shoots were transported to aseptic conditions in a laminar air hood. They were then surface sterilized with $20 \%$ sodium hypochlorite $(\mathrm{NaOCl})$ for 10 min and rinsed with autoclaved water $3-5$ times. Then, explants were disinfected with $0.5 \%(\mathrm{w} / \mathrm{v}) \mathrm{HgCl}_{2}$ for $15 \mathrm{~min}$ and rinsed with sterilized distilled water for $5 \mathrm{~min}$. Finally, they were placed in the 5\% ethanol for $5 \mathrm{~min}$ and then fully rinsed with sterilized distilled water. Under aseptic conditions in a laminar air hood, shoot tips $(8-10 \mathrm{~mm})$ were excised from the shoots and used as explant (Fig. 2A).

\section{Culture medium, treatments, and measured parameters}

The surface-sterilized explants were cultured in MS (Murashige and Skoog, 1962) medium fortified with 0.50, 1.00 and $2.00 \mathrm{mg} / \mathrm{l}$ of KIN and IBA or no PGRs as control. Sucrose (3\%) was used as carbon source and media were solidified with Agar-agar (0.8\%). The $\mathrm{pH}$ of the medium was adjusted to $5.7 \pm 0.10$ and autoclaved at $15 \mathrm{psi}, 121^{\circ} \mathrm{C}$ for $30 \mathrm{~min}$. The cultures were maintained in a growth chamber at $24 \pm 1^{\circ} \mathrm{C}$ with a 16 -h photoperiod and a photosynthetic photon density flux of $50 \mu \mathrm{mol} \mathrm{m}^{-2} \mathrm{~s}^{-1}$ provided by cool white fluorescent lamps and $75-80 \%$ RH. After 2 months of culture, the parameters including leaf length, leaf diameter, leaf number, root length, root number and viability percentage of plantlets were calculated.

\section{Plantlets acclimatization}

In vitro rooted plantlets were washed with sterile water to remove the nutrient agar adhered to the roots and were cultivated in plastic pots containing peat and perlite (in a ratio of $1: 1$ ). Plantlets were covered by thin plastic bags, transferred to the greenhouse and kept at $25 \pm 1^{\circ} \mathrm{C}$ and $70-80 \% \mathrm{RH}$. They were then watered regularly and were exposed gradually to external environment by removing the plastic bags around the pots.

\section{Experimental design}

A factorial experiment in a completely randomized design was conducted. The experiment consisted of four replicates with one plant per replicate. Data were recorded from 200 explants after 8 weeks of culture. All the statistical analyses were carried out using Statistical Package for Social Sciences (SPSS) v 16.0. The ANOVA procedure for factorial experiments was used to test whether the treatments had significant effects; this was followed by least significant difference (LSD) test for comparisons of different means of different treatments.

\section{Results}

\section{Effect of PGRs on in vivo propagation of stem cuttings}

Stem cuttings treated with different concentrations of KIN and IBA showed varied responses (Tables 1-3, Fig. 1). Adventitious roots were emerged 4-5 weeks after imposing of treatments. KIN and IBA at 500, 1000 and $2000 \mathrm{mg} / 1$ were tested for their influence on the number of roots produced per shoot and the root length in B. hyrcana (Fig. 1E). It was observed that $100 \%$ of the shoots tested produced roots following the different KIN and IBA treatments (including the control). A significantly higher number of roots were generated on shoots in the presence of $500 \mathrm{mg} / \mathrm{KIN}$ and $1000 \mathrm{mg} / \mathrm{l}$ IBA (16.80) compared to the control (6.10). Shoots subjected to KIN and IBA treatments at 1000 and $2000 \mathrm{mg} / \mathrm{l}$, respectively, also produced a high number of roots (14.23) (Table 3). Treatments without the presence of IBA yielded the least number of roots (with an average of 7.15) per shoot. Tables 1 and 2 show that among all treatments containing KIN and IBA used alone, higher number of roots were generated on shoots in the presence of 500 and $1000 \mathrm{mg} / \mathrm{l} \mathrm{IBA} \mathrm{(11.78} \mathrm{and}$ 10.45 , respectively). The concentration of $1000 \mathrm{mg} / \mathrm{l}$ $\mathrm{KIN}$ in combination with $1000 \mathrm{mg} / \mathrm{l} \mathrm{IBA}$ resulted in the best values of the length of the root $(8.16 \mathrm{~cm}$ per cutting) (Fig. 1E). The treatments of 500 and $2000 \mathrm{mg} / \mathrm{l}$ IBA without the presence of KIN also showed promising effects on the root length (more than $7.00 \mathrm{~cm}$ ) (Ta- 

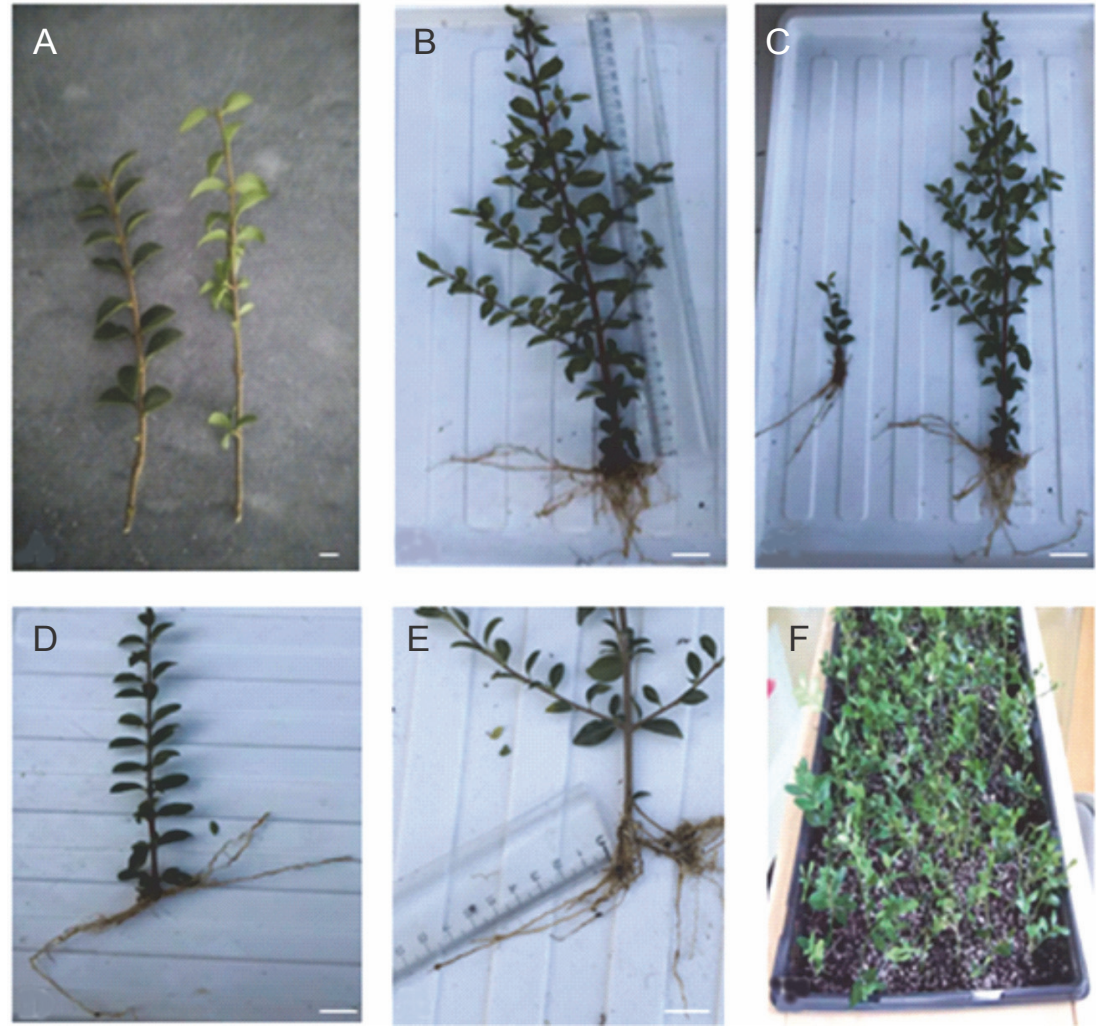

Fig. 1. Root and shoot induction on stem cuttings of Buxus hyrcana induced by different concentrations of KIN and IBA. A) standardized stem cuttings; B) plantlets height (treated with $1000 \mathrm{mg} / \mathrm{lBA}$ ); C) shoot number (treated with $500 \mathrm{mg} / \mathrm{l} \mathrm{KIN}$ plus $1000 \mathrm{mg} / \mathrm{l} \mathrm{IBA} \mathrm{-} \mathrm{right} \mathrm{and} \mathrm{control} \mathrm{-} \mathrm{left);} \mathrm{D)} \mathrm{node}$ number (treated with $500 \mathrm{mg} / \mathrm{l} \mathrm{IBA}$ ); E) root length (treated with $1000 \mathrm{mg} / \mathrm{l}$ KIN plus $1000 \mathrm{mg} / 1 \mathrm{IBA}) ; \mathrm{F}$ ) acclimatized plants in tray (scale bar $=1 \mathrm{~cm}$ )

Table 1. Mean comparison of the effect of different concentrations of KIN on measured parameters of Buxus hyrcana (in vivo conditions)

\begin{tabular}{c|c|c|c|c|c|c|c|c}
\hline $\begin{array}{c}\text { KIN } \\
{[\mathrm{mg} / \mathrm{l}]}\end{array}$ & $\begin{array}{c}\text { Node } \\
\text { number }\end{array}$ & $\begin{array}{c}\text { Plantlet } \\
\text { height } \\
{[\mathrm{cm}]}\end{array}$ & $\begin{array}{c}\text { Shoot } \\
\text { number }\end{array}$ & $\begin{array}{c}\text { Root } \\
\text { length } \\
{[\mathrm{cm}]}\end{array}$ & $\begin{array}{c}\text { Root } \\
\text { number }\end{array}$ & $\begin{array}{c}\text { Length } \\
\text { of the } \\
\text { longest root }\end{array}$ & $\begin{array}{c}\text { Stem } \\
\text { diameter } \\
{[\mathrm{cm}]}\end{array}$ & $\begin{array}{c}\text { Leaf } \\
\text { number }\end{array}$ \\
\hline 0 & $10.67^{\mathrm{a}}$ & $23.57^{\mathrm{a}}$ & $6.40^{\mathrm{b}}$ & $6.75^{\mathrm{a}}$ & $6.68^{\mathrm{c}}$ & $6.19^{\mathrm{a}}$ & $0.36^{\mathrm{a}}$ & $80.00^{\mathrm{a}}$ \\
\hline 500 & $6.34^{\mathrm{d}}$ & $15.20^{\mathrm{c}}$ & $7.67^{\mathrm{a}}$ & $6.62^{\mathrm{a}}$ & $7.85^{\mathrm{b}}$ & $6.95^{\mathrm{a}}$ & $0.38^{\mathrm{a}}$ & $84.30^{\mathrm{a}}$ \\
\hline 1000 & $8.58^{\mathrm{c}}$ & $15.91^{\mathrm{c}}$ & $6.98^{\mathrm{ab}}$ & $6.56^{\mathrm{a}}$ & $8.32^{\mathrm{a}}$ & $7.29^{\mathrm{a}}$ & $0.36^{\mathrm{a}}$ & $82.50^{\mathrm{a}}$ \\
\hline 2000 & $9.61^{\mathrm{b}}$ & $18.22^{\mathrm{b}}$ & $7.05^{\mathrm{ab}}$ & $6.84^{\mathrm{a}}$ & $6.94^{\mathrm{c}}$ & $6.77^{\mathrm{a}}$ & $0.40^{\mathrm{a}}$ & $84.30^{\mathrm{a}}$ \\
\hline
\end{tabular}

Means with different letters on the same column are significantly different $(P<0.05)$ based on LSD test

ble 3). Differences between root length in cuttings treated with each one of KIN and IBA singly were not significant (data not shown). The longest root $(11.40 \mathrm{~cm})$ was obtained with the treatment of $1000 \mathrm{mg} / 1 \mathrm{KIN}$ (Table 3). The longest root obtained under control (without application of KIN and IBA) was 4.06.
Shoots in the control (without KIN and IBA) produced significantly more node compared to those in the presence of all KIN and IBA treatments, alone or in combination (Table 3 ). However, there were many nodes on shoots treated with $500 \mathrm{mg} / \mathrm{l}$ (Fig. 1D) and $2000 \mathrm{mg} / \mathrm{l}$ KIN plus $500 \mathrm{mg} / \mathrm{l}$ IBA (Table 3). Treatments 
Table 2. Mean comparison of the effect of different concentrations of IBA on measured parameters of Buxus hyrcana (in vivo conditions)

\begin{tabular}{c|c|c|c|c|c|c|c|c}
\hline $\begin{array}{c}\text { IBA } \\
{[\mathrm{mg} / \mathrm{l}]}\end{array}$ & $\begin{array}{c}\text { Node } \\
\text { number }\end{array}$ & $\begin{array}{c}\text { Plantlet } \\
\text { height } \\
{[\mathrm{cm}]}\end{array}$ & $\begin{array}{c}\text { Shoot } \\
\text { number }\end{array}$ & $\begin{array}{c}\text { Root } \\
\text { length } \\
{[\mathrm{cm}]}\end{array}$ & $\begin{array}{c}\text { Root } \\
\text { number }\end{array}$ & $\begin{array}{c}\text { Length } \\
\text { of the } \\
\text { longest root }\end{array}$ & $\begin{array}{c}\text { Stem } \\
\text { diameter } \\
{[\mathrm{cm}]}\end{array}$ & $\begin{array}{c}\text { Leaf } \\
\text { number }\end{array}$ \\
\hline 0 & $10.45^{\mathrm{a}}$ & $16.84^{\mathrm{b}}$ & $5.48^{\mathrm{c}}$ & $6.87^{\mathrm{a}}$ & $6.89^{\mathrm{d}}$ & $6.31^{\mathrm{ab}}$ & $0.31^{\mathrm{b}}$ & $74.80^{\mathrm{c}}$ \\
\hline 500 & $9.32^{\mathrm{b}}$ & $18.35^{\mathrm{a}}$ & $6.44^{\mathrm{b}}$ & $6.80^{\mathrm{a}}$ & $11.78^{\mathrm{a}}$ & $5.08^{\mathrm{b}}$ & $0.45^{\mathrm{a}}$ & $69.00^{\mathrm{d}}$ \\
\hline 1000 & $6.25^{\mathrm{c}}$ & $19.24^{\mathrm{a}}$ & $8.05^{\mathrm{a}}$ & $6.53^{\mathrm{a}}$ & $10.45^{\mathrm{b}}$ & $7.58^{\mathrm{a}}$ & $0.43^{\mathrm{a}}$ & $90.10^{\mathrm{b}}$ \\
\hline 2000 & $9.18^{\mathrm{b}}$ & $18.49^{\mathrm{a}}$ & $8.14^{\mathrm{a}}$ & $6.56^{\mathrm{a}}$ & $9.21^{\mathrm{c}}$ & $8.23^{\mathrm{a}}$ & $0.30^{\mathrm{b}}$ & $97.30^{\mathrm{a}}$ \\
\hline
\end{tabular}

Means with different letters on the same column are significantly different $(P<0.05)$ based on LSD test

with $1000 \mathrm{mg} / \mathrm{l} \mathrm{IBA}$ and control induced faster growth of shoots in relation to the other treatments $(P<0.01)$, with 26.70 and $24.30 \mathrm{~cm}$ length at 65 days, respectively (Table 3). The lowest value of the length of the shoots was obtained with the treatment of $500 \mathrm{mg} / \mathrm{l} \mathrm{KIN}$; this treatment resulted in shoots $9.20 \mathrm{~cm}$ long. Needless to say, too high length of plantlets is not an advantage for ornamental species from aesthetic point of view; the ornamentals with more compact shoots are more beautiful.

The treatment without KIN and IBA (control) produced only 3.60 shoots $(P<0.01)$ and 42.30 leaves $(P<0.01$ for KIN together with IBA and IBA alone, not for KIN alone) per cutting at 65 days (data not shown). The concentrations of $1000 \mathrm{mg} / \mathrm{l} \mathrm{KIN}$ and $2000 \mathrm{mg} / \mathrm{l} \mathrm{IBA}$ induced the maximum shoot number (9.26) (Fig. 1C) and leaf number (105.00) per cutting (Table 3). These amounts are about three fold higher than those of produced in control cuttings. Table 3 shows the production of more than 8 shoots per cutting when 500 or $2000 \mathrm{mg} / \mathrm{l}$ KIN in combination with 500,1000 or $2000 \mathrm{mg} / \mathrm{l}$ IBA were applied. This result suggests the importance of applying both KIN and IBA for achieving greater number of shoots and leaves. There was no positive relationship between increasing KIN and IBA concentrations and increase in the number of shoots and leaves (Table 3). The concentration of $1000 \mathrm{mg} / \mathrm{l} \mathrm{KIN}$ along with $500 \mathrm{mg} / \mathrm{l}$ IBA and $2000 \mathrm{mg} / \mathrm{l} \mathrm{KIN}$ along with $1000 \mathrm{mg} / \mathrm{l} \mathrm{IBA}$ resulted in better values for the stem diameter (both with $0.53 \mathrm{~cm}$ per cutting) (Table 3). The treatment without KIN and the treatment containing the highest concentrations of KIN and IBA showed least effects on stem diameters.

\section{Effect of PGRs on in vitro propagation of shoot tips}

The number, length and width of leaves formed per shoot explants were strongly dependent on the composition of media. Successful leaf length $(2.26$ and $2.70 \mathrm{~cm}$ per explant) was obtained in media fortified with $2.00 \mathrm{mg} / \mathrm{l} \mathrm{KIN}$ together with $1.00 \mathrm{mg} / \mathrm{l} \mathrm{IBA}$, and 1.00 $\mathrm{mg} / \mathrm{l} \mathrm{KIN}$ together with $1.00 \mathrm{mg} / \mathrm{l} \mathrm{IBA}$, respectively (Table 6, Fig. 2D). Minimum leaf length $(0.96 \mathrm{~cm})$ was calculated in a medium without KIN and IBA (control). Medium with $0.50 \mathrm{mg} / 1 \mathrm{KIN}$ and $0.50 \mathrm{mg} / 1 \mathrm{IBA}$ formed leaves with a low frequency (8.10 per explant) - Table 6 . A combination of $2.00 \mathrm{mg} / 1 \mathrm{KIN}$ and $0.50 \mathrm{mg} / \mathrm{l} \mathrm{IBA}$ was found to be the most suitable PGRs regime, achieving the largest number of leaves with 11.43 leaves per explant (Table 6, Fig. 2B). IBA at a concentration of $1.00 \mathrm{mg} / \mathrm{l}$ was found to be more effective for leaf width (Fig. 2E). The combination of $2.00 \mathrm{mg} / \mathrm{l} \mathrm{KIN}$ and $0.50 \mathrm{mg} / \mathrm{l} \mathrm{IBA}$ also did not improve the leaf width. Plantlets produced in media containing $2.00 \mathrm{mg} / \mathrm{l} \mathrm{IBA}, 2.00 \mathrm{mg} / \mathrm{l} \mathrm{KIN}$, and $0.50 \mathrm{mg} / 1 \mathrm{KIN}$ together with $1.00 \mathrm{mg} / \mathrm{l} \mathrm{IBA}$ showed $90 \%$ viability percentage (Table 6 ).

Table 6 shows that different concentrations of PGRs combinations may induce different rates of root length and root number. We found that the application of $2.00 \mathrm{mg} / \mathrm{KIN}$ alone resulted in the highest length of root (9.60) and the largest number of roots (6.10) per explant (Fig. $2 \mathrm{G}$ and Fig. $2 \mathrm{H}$ ). The explants treated with $1.00 \mathrm{mg} / 1 \mathrm{KIN}$ in combination with $1.00 \mathrm{mg} / \mathrm{l} \mathrm{IBA}$ produced the same root number (6.50) as those on $2.00 \mathrm{mg} / 1$ KIN containing medium (Table 6 ). The poorest rooting $(6.00 \mathrm{~cm}$ in length and 3.50 in number) was noticed on shoot tips cultured on media without PGRs. KIN at $2.00 \mathrm{mg} / \mathrm{l}$ was better than the other KIN concentrations 
Table 3. Mean comparison of the effect of different concentrations of KIN and IBA on measured parameters of Buxus hyrcana (in vivo conditions)

\begin{tabular}{|c|c|c|c|c|c|c|c|c|}
\hline $\begin{array}{c}\mathrm{KIN} \times \mathrm{IBA} \\
{[\mathrm{mg} / \mathrm{l}]}\end{array}$ & Node number & $\begin{array}{l}\text { Plantlet height } \\
{[\mathrm{cm}]}\end{array}$ & Shoot number & $\begin{array}{l}\text { Root length } \\
{[\mathrm{cm}]}\end{array}$ & Root number & $\begin{array}{c}\text { Length } \\
\text { of the longest root }\end{array}$ & $\begin{array}{l}\text { Stem diameter } \\
{[\mathrm{cm}]}\end{array}$ & Leaf number \\
\hline $0 \times 0$ & $14.50^{\mathrm{a}} \pm 0.50$ & $24.30^{\mathrm{a}} \pm 3.29$ & $3.60^{\mathrm{e}} \pm 0.00$ & $6.50^{\mathrm{ab}} \pm 0.50$ & $6.10^{\mathrm{h}} \pm 0.50$ & $4.06^{\mathrm{f}} \pm 0.56$ & $0.33^{\mathrm{bc}} \pm 0.05$ & $42.3^{g} \pm 0.57$ \\
\hline $0 \times 500$ & $12.50^{\mathrm{b}} \pm 1.32$ & $21.00^{\mathrm{bc}} \pm 0.50$ & $7.83^{\mathrm{ab}} \pm 0.15$ & $7.36^{\mathrm{a}} \pm 0.30$ & $12.12^{\mathrm{c}} \pm 1.20$ & $4.80^{\mathrm{ef}} \pm 1.21$ & $0.36^{\mathrm{b}} \pm 0.05$ & $86.3^{\mathrm{c}-\mathrm{e}} \pm 2.88$ \\
\hline $0 \times 1000$ & $6.50^{\mathrm{fg}} \pm 0.50$ & $26.70^{\mathrm{a}} \pm 0.72$ & $6.96^{\mathrm{bc}} \pm 0.63$ & $5.70^{\mathrm{b}} \pm 0.40$ & $10.44^{\mathrm{cd}} \pm 1.21$ & $8.80^{\mathrm{abc}} \pm 3.27$ & $0.47^{\mathrm{a}} \pm 0.00$ & $90.0^{\mathrm{cd}} \pm 9.00$ \\
\hline $0 \times 2000$ & $9.20^{\mathrm{cd}} \pm 0.26$ & $20.30^{\mathrm{cd}} \pm 0.20$ & $6.23^{c} \pm 1.95$ & $7.43^{\mathrm{a}} \pm 0.40$ & $8.56^{\text {cde }} \pm 0.43$ & $5.80^{\mathrm{b}-\mathrm{f}} \pm 1.94$ & $0.26^{\mathrm{c}} \pm 0.05$ & $101.6^{\mathrm{ab}} \pm 4.50$ \\
\hline $500 \times 0$ & $6.83^{\mathrm{e}-\mathrm{g}} \pm 0.35$ & $9.20^{j} \pm 0.17$ & $4.56^{\mathrm{d}} \pm 2.03$ & $6.86^{\mathrm{a}} \pm 1.06$ & $7.54^{\mathrm{de}} \pm 0.32$ & $4.80^{\mathrm{ef}} \pm 1.21$ & $0.33^{\mathrm{bc}} \pm 0.05$ & $81.3^{\mathrm{d}-\mathrm{f}} \pm 6.65$ \\
\hline $500 \times 500$ & $5.50^{\mathrm{gh}} \pm 0.86$ & $22.70^{b} \pm 0.17$ & $8.76^{a} \pm 1.20$ & $6.50^{\mathrm{ab}} \pm 0.50$ & $13.78^{\mathrm{ab}} \pm 1.02$ & $4.36^{\mathrm{f}} \pm 0.56$ & $0.46^{\mathrm{a}} \pm 0.05$ & $76.0^{\mathrm{ef}} \pm 3.00$ \\
\hline $500 \times 1000$ & $7.86^{\mathrm{d}-\mathrm{f}} \pm 0.28$ & $14.93^{\mathrm{gh}} \pm 0.40$ & $8.93^{\mathrm{a}} \pm 0.73$ & $6.56^{\mathrm{ab}} \pm 0.66$ & $16.80^{a} \pm 0.60$ & $9.86^{\mathrm{ab}} \pm 1.64$ & $0.36^{\mathrm{b}} \pm 0.05$ & $88.6^{\mathrm{cd}} \pm 3.21$ \\
\hline $500 \times 2000$ & $8.86^{\mathrm{cd}} \pm 0.32$ & $14.00^{\mathrm{hi}} \pm 1.30$ & $8.73^{a} \pm 0.41$ & $6.56^{\mathrm{ab}} \pm 0.57$ & $11.86^{\text {cd }} \pm 0.75$ & $8.80^{\mathrm{a}-\mathrm{e}} \pm 4.20$ & $0.36^{b} \pm 0.02$ & $91.3^{b-d} \pm 3.05$ \\
\hline $1000 \times 0$ & $10.20^{\mathrm{c}} \pm 1.21$ & $12.83^{\mathrm{i}} \pm 0.45$ & $6.53^{\mathrm{bc}} \pm 0.77$ & $6.70^{\mathrm{a}} \pm 0.43$ & $8.10^{\text {cde }} \pm 1.04$ & $11.40^{\mathrm{a}} \pm 2.90$ & $0.26^{\mathrm{c}} \pm 0.05$ & $94.3^{\mathrm{a}-\mathrm{c}} \pm 8.51$ \\
\hline $1000 \times 500$ & $6.46^{\mathrm{fg}} \pm 2.66$ & $17.23^{\mathrm{ef}} \pm 1.47$ & $4.60^{\mathrm{d}} \pm 0.20$ & $6.50^{\mathrm{ab}} \pm 0.50$ & $9.67^{\mathrm{d}} \pm 0.47$ & $4.26^{\mathrm{f}} \pm 0.15$ & $0.53^{a} \pm 0.05$ & $45.0^{g} \pm 2.65$ \\
\hline $1000 \times 1000$ & $7.50^{\mathrm{d}-\mathrm{f}} \pm 1.32$ & $16.43^{\mathrm{fg}} \pm 1.00$ & $7.83^{\mathrm{ab}} \pm 0.85$ & $8.16^{\mathrm{a}} \pm 0.30$ & $12.42^{\mathrm{c}} \pm 1.28$ & $5.53^{\mathrm{c}-\mathrm{f}} \pm 2.10$ & $0.33^{b c} \pm 0.05$ & $90.0^{\mathrm{cd}} \pm 6.00$ \\
\hline $1000 \times 2000$ & $10.16^{c} \pm 0.75$ & $17.16^{\text {ef }} \pm 1.80$ & $9.26^{\mathrm{a}} \pm 0.47$ & $5.70^{\mathrm{b}} \pm 0.40$ & $14.23^{\mathrm{ab}} \pm 0.87$ & $9.16^{\mathrm{a}-\mathrm{d}} \pm 4.35$ & $0.33^{\mathrm{bc}} \pm 0.05$ & $105.0^{\mathrm{a}} \pm 2.64$ \\
\hline $2000 \times 0$ & $10.26^{\mathrm{c}} \pm 0.80$ & $19.03^{\mathrm{c}-\mathrm{e}} \pm 1.15$ & $6.23^{c} \pm 0.15$ & $6.83^{\mathrm{a}} \pm 0.40$ & $6.89^{\mathrm{f}-\mathrm{g}} \pm 0.48$ & $5.70^{\mathrm{b}-\mathrm{f}} \pm 2.11$ & $0.33^{b c} \pm 0.05$ & $81.3^{\mathrm{d}-\mathrm{f}} \pm 6.65$ \\
\hline $2000 \times 500$ & $12.83^{\mathrm{ab}} \pm 1.25$ & $12.46^{\mathrm{i}} \pm 0.97$ & $4.56^{\mathrm{d}} \pm 0.28$ & $6.56^{\mathrm{ab}} \pm 1.06$ & $10.54^{\mathrm{cd}} \pm 0.86$ & $7.10^{\mathrm{a}-\mathrm{f}} \pm 4.63$ & $0.46^{\mathrm{a}} \pm 0.05$ & $72.6^{\mathrm{f}} \pm 7.51$ \\
\hline $2000 \times 1000$ & $6.84^{\mathrm{e}-\mathrm{g}} \pm 0.43$ & $18.90^{\mathrm{de}} \pm 1.24$ & $8.76^{\mathrm{a}} \pm 0.37$ & $6.50^{\mathrm{ab}} \pm 0.50$ & $10.76^{\mathrm{cd}} \pm 0.90$ & $5.13^{\mathrm{d}-\mathrm{f}} \pm 1.88$ & $0.53^{\mathrm{a}} \pm 0.05$ & $92.0^{b-d} \pm 5.64$ \\
\hline $2000 \times 2000$ & $8.50^{\text {cde }} \pm 1.80$ & $22.50^{\mathrm{b}} \pm 0.50$ & $8.63^{a} \pm 0.55$ & $6.56^{\mathrm{ab}} \pm 0.66$ & $6.60^{\mathrm{f}-\mathrm{g}} \pm 0.88$ & $9.16^{\mathrm{a}-\mathrm{d}} \pm 1.68$ & $0.26^{\mathrm{c}} \pm 0.05$ & $91.3^{b-d} \pm 6.05$ \\
\hline
\end{tabular}

Means with different letters on the same column are significantly different $(P<0.05)$ based on LSD test; mean \pm std. dev. 
Table 4. Mean comparison of the effect of different concentrations of KIN on measured parameters of Buxus hyrcana (in vitro conditions)

\begin{tabular}{c|c|c|c|c|c|c}
\hline $\begin{array}{c}\text { KIN } \\
{[\mathrm{mg} / \mathrm{l}]}\end{array}$ & $\begin{array}{c}\text { Root } \\
\text { length } \\
{[\mathrm{cm}]}\end{array}$ & $\begin{array}{c}\text { Leaf } \\
\text { length } \\
{[\mathrm{cm}]}\end{array}$ & $\begin{array}{c}\text { Leaf } \\
\text { diameter } \\
{[\mathrm{cm}]}\end{array}$ & $\begin{array}{c}\text { Leaf } \\
\text { number }\end{array}$ & $\begin{array}{c}\text { Root } \\
\text { number }\end{array}$ & $\begin{array}{c}\text { Viability } \\
\text { percentage }\end{array}$ \\
\hline 0.00 & $6.67^{\mathrm{c}}$ & $1.50^{\mathrm{c}}$ & $0.79^{\mathrm{a}}$ & $9.22^{\mathrm{b}}$ & $4.60^{\mathrm{b}}$ & $78.30^{\mathrm{ab}}$ \\
\hline 0.50 & $7.14^{\mathrm{bc}}$ & $1.60^{\mathrm{bc}}$ & $0.76^{\mathrm{ab}}$ & $9.13^{\mathrm{b}}$ & $5.22^{\mathrm{a}}$ & $81.80^{\mathrm{a}}$ \\
\hline 1.00 & $7.53^{\mathrm{b}}$ & $1.84^{\mathrm{a}}$ & $0.66^{\mathrm{bc}}$ & $9.60^{\mathrm{ab}}$ & $5.25^{\mathrm{a}}$ & $75.80^{\mathrm{b}}$ \\
\hline 2.00 & $8.47^{\mathrm{a}}$ & $1.66^{\mathrm{b}}$ & $0.62^{\mathrm{c}}$ & $10.18^{\mathrm{a}}$ & $5.21^{\mathrm{a}}$ & $81.60^{\mathrm{a}}$ \\
\hline
\end{tabular}

Means with different letters on the same column are significantly different $(P<0.05)$ based on LSD test

Table 5. Mean comparison of the effect of different concentrations of IBA on measured parameters of Buxus hyrcana (in vitro conditions)

\begin{tabular}{c|c|c|c|c|c|c}
\hline $\begin{array}{c}\text { IBA } \\
{[\mathrm{mg} / \mathrm{l}]}\end{array}$ & $\begin{array}{c}\text { Root } \\
\text { length } \\
{[\mathrm{cm}]}\end{array}$ & $\begin{array}{c}\text { Leaf } \\
\text { length } \\
{[\mathrm{cm}]}\end{array}$ & $\begin{array}{c}\text { Leaf } \\
\text { diameter } \\
{[\mathrm{cm}]}\end{array}$ & $\begin{array}{c}\text { Leaf } \\
\text { number }\end{array}$ & $\begin{array}{c}\text { Root } \\
\text { number }\end{array}$ & $\begin{array}{c}\text { Viability } \\
\text { percentage }\end{array}$ \\
\hline 0.00 & $7.41^{\mathrm{a}}$ & $1.38^{\mathrm{d}}$ & $0.71^{\mathrm{a}}$ & $9.66^{\mathrm{a}}$ & $5.17^{\mathrm{a}}$ & $75.16^{\mathrm{b}}$ \\
\hline 0.50 & $7.15^{\mathrm{a}}$ & $1.50^{\mathrm{c}}$ & $0.65^{\mathrm{a}}$ & $9.81^{\mathrm{a}}$ & $4.62^{\mathrm{b}}$ & $83.33^{\mathrm{a}}$ \\
\hline 1.00 & $7.43^{\mathrm{a}}$ & $1.94^{\mathrm{a}}$ & $0.74^{\mathrm{a}}$ & $9.44^{\mathrm{a}}$ & $5.36^{\mathrm{a}}$ & $75.00^{\mathrm{b}}$ \\
\hline 2.00 & $7.82^{\mathrm{a}}$ & $1.79^{\mathrm{b}}$ & $0.74^{\mathrm{a}}$ & $9.22^{\mathrm{a}}$ & $5.13^{\mathrm{a}}$ & $84.16^{\mathrm{a}}$ \\
\hline
\end{tabular}

Means with different letters on the same column are significantly different $(P<0.05)$ based on LSD test

as determined by measured root length. There was no significant difference in the length of roots per explants treated with different concentrations of IBA. Other treatments showed significant differences in root length and root number (data not shown).

Plantlets were acclimatized in the plant growth chamber benefited from the high humidity and other incubation conditions during the 2 weeks and showed 95\% survival (Fig. 2I and Fig. 2J). Plantlets were then taken out of the growth chamber and transferred to an adaptation greenhouse for another 2 weeks after repotting in pots containing a mixture of peat and perlite (in ratio of $1: 1)$. All the acclimatized plantlets were successfully established and formed new leaflets (Fig. 2H). Acclimatized plants had normal leaf development and lacked detectable morphological variation and showed apparently uniform growth and true-to-type morphology.

\section{Discussion}

\section{In vivo propagation}

B. hyrcana is a species critically at the risk of extinction mainly due to the invasion of pathogens (Kaviani and Negahdar, 2017). The main pathogen is a type of witch moth, Cydalima perspectalis. The population of B. hyrcana in northern part of Iran has been reduced to $20-30 \%$. This plant has great commercial potential. Boxwoods are evergreen shrubs and trees; they are popular in gardens and landscapes (Kaviani and Negahdar, 2017). Thus, they should be protected. Propagation by rooting of semi-hard wood cuttings and in vitro propagation are the effective methods for conservation and rapid multiplication of the species in danger of extinction. Effective production of shoots and adventitious roots in plant tissue culture laboratory and greenhouse ensures a constant production of clones throughout the year. Just a single work was reported (by the authors of this article) about propagation and micropropagation of B. hycana Pojark (Kaviani and Negadar, 2017).

In the current study, B. hyrcana responded positively to rooting in concentrations of 500 and $1000 \mathrm{mg} / \mathrm{l} \mathrm{IBA}$. Authors in their previous study revealed that $1000 \mathrm{mg} / 1$ IBA along with $1000 \mathrm{mg} / 1 \mathrm{NAA}$ induced the largest number of roots per cutting (Kaviani and Negahdar, 2017). Similar findings were reported on other trees and 

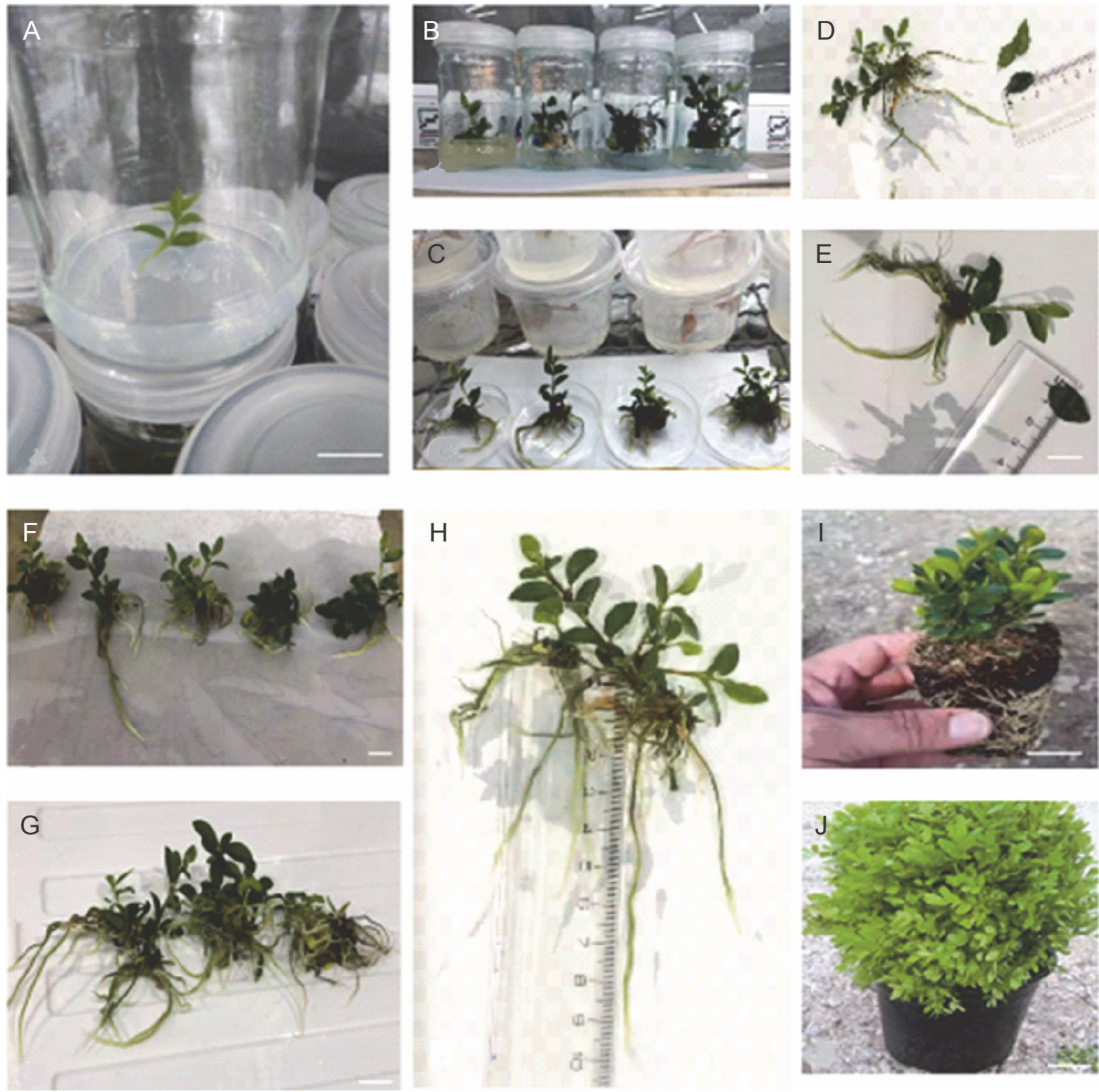

Fig. 2. In vitro development of Buxus hyrcana. A) early stage of in vitro culture (the explants were shoot apex $(\mathrm{scale} b a r=1 \mathrm{~cm})$ ); B) shoot multiplication from explants cultured on Murashige and Skoog (MS) medium containing different concentrations of KIN and IBA; C) fully developed plantlets out of culture media; D) measurement of leaf length; E) measurement of leaf width; F) plantlets containing shoots and roots ready for acclimatization; G) regenerated plantlets from media containing different concentrations of KIN and IBA with fully developed roots; H) measurement of root length; I) acclimatization phase; J) viable ex vitro plants growing under standard greenhouse conditions (scale bar $=2 \mathrm{~cm}$ except for $\mathrm{A}$ )

shrubs species such as Pausinystalia johimbe and Pongamia pinnata (Hartmann et al., 2002; Tchoundjeu et al., 2004; Kesari et al., 2009). Auxins, natural or artificially applied, are known to play a significant role in stimulating root initiation in stem cuttings of woody species (Hartmann et al., 2011). The application of auxins in the basal region of cuttings and mini-cuttings is prevalent worldwide to promote the adventitious rooting of woody species (Hartmann et al., 2011; Brondani et al., 2012). A great variation was observed among the types, concentrations, formulations and forms of application (Wendling et al., 2010; Brondani et al., 2012). It is well known that IBA is the most widely used auxin for the induction of adventitious roots in vegetative propagules, but the concentrations should be adjusted to obtain better rooting rates (Corrêa and Fett-Neto, 2004; Kaviani and Negahdar, 2017). Adventitious rooting appears to be particularly controlled by endogenous levels of auxins (Zhu et al., 2010). Exogenous application of auxins in appropriate concentration enhances the rooting induction 
Table 6. Mean comparison of the effect of different concentrations of KIN and IBA on measured parameters of Buxus hyrcana (in vitro conditions)

\begin{tabular}{|c|c|c|c|c|c|c|}
\hline $\begin{array}{c}\mathrm{KIN} \times \mathrm{IBA} \\
{[\mathrm{mg} / \mathrm{l}]}\end{array}$ & $\begin{array}{l}\text { Root length } \\
{[\mathrm{cm}]}\end{array}$ & $\begin{array}{l}\text { Leaf length } \\
{[\mathrm{cm}]}\end{array}$ & $\begin{array}{l}\text { Leaf width } \\
{[\mathrm{cm}]}\end{array}$ & Leaf number & Root number & $\begin{array}{c}\text { Viability } \\
\text { percentage }\end{array}$ \\
\hline $0.00 \times 0.00$ & $6.00^{\mathrm{e}} \pm 0.60$ & $0.96^{\mathrm{g}} \pm 0.20$ & $0.60^{\mathrm{de}} \pm 0.10$ & $9.00^{c-f} \pm 1.15$ & $3.50^{\mathrm{g}} \pm 0.52$ & $70.00^{\mathrm{ef}} \pm 0.00$ \\
\hline $0.00 \times 0.50$ & $6.10^{\mathrm{e}} \pm 0.40$ & $1.06^{\mathrm{g}} \pm 0.20$ & $0.80^{\mathrm{a}-\mathrm{d}} \pm 0.10$ & $10.10^{\mathrm{bc}} \pm 0.90$ & $3.93^{g} \pm 0.15$ & $86.60^{\mathrm{ab}} \pm 5.77$ \\
\hline $0.00 \times 1.00$ & $6.53^{\mathrm{de}} \pm 0.49$ & $1.90^{\mathrm{bc}} \pm 0.10$ & $0.90^{\mathrm{a}} \pm 0.10$ & $9.26^{\mathrm{c}-\mathrm{f}} \pm 1.40$ & $5.10^{\mathrm{c}-\mathrm{e}} \pm 0.45$ & $66.60^{\mathrm{f}} \pm 5.77$ \\
\hline $0.00 \times 2.00$ & $7.73^{\text {bcd }} \pm 1.01$ & $1.95^{b c} \pm 0.10$ & $0.86^{\mathrm{ab}} \pm 0.05$ & $8.53^{\mathrm{ef}} \pm 0.35$ & $4.90^{\mathrm{d}-\mathrm{f}} \pm 0.10$ & $90.00^{a} \pm 5.00$ \\
\hline $0.50 \times 0.00$ & $6.30^{\mathrm{e}} \pm 0.45$ & $1.63^{\mathrm{def}} \pm 0.15$ & $0.83^{a-c} \pm 0.05$ & $9.16^{\mathrm{c}-\mathrm{f}} \pm 1.10$ & $4.33^{\mathrm{fg}} \pm 0.15$ & $70.60^{\text {ef }} \pm 4.50$ \\
\hline $0.50 \times 0.50$ & $7.20^{\mathrm{b}-\mathrm{e}} \pm 0.36$ & $1.63^{\mathrm{def}} \pm 0.15$ & $0.70^{\mathrm{a}-\mathrm{d}} \pm 0.00$ & $8.10^{f} \pm 0.70$ & $5.36^{\mathrm{a}-\mathrm{d}} \pm 0.20$ & $86.60^{\mathrm{ab}} \pm 5.77$ \\
\hline $0.50 \times 1.00$ & $6.93^{\text {cde }} \pm 0.96$ & $1.40^{\mathrm{f}} \pm 0.10$ & $0.76^{\mathrm{a}-\mathrm{d}} \pm 0.20$ & $9.53^{\mathrm{b}-\mathrm{e}} \pm 0.40$ & $5.33^{\mathrm{b}-\mathrm{d}} \pm 0.25$ & $90.00^{\mathrm{a}} \pm 0.00$ \\
\hline $0.50 \times 2.00$ & $8.13^{b c} \pm 1.28$ & $1.73^{\text {cde }} \pm 0.11$ & $0.76^{\mathrm{a}-\mathrm{d}} \pm 0.05$ & $9.43^{\mathrm{b}-\mathrm{f}} \pm 0.80$ & $5.86^{\mathrm{ab}} \pm 0.65$ & $80.00^{b-d} \pm 0.00$ \\
\hline $1.00 \times 0.00$ & $7.43^{\mathrm{b}-\mathrm{e}} \pm 0.41$ & $1.40^{\mathrm{f}} \pm 0.10$ & $0.63^{\mathrm{cd}} \pm 0.11$ & $10.43^{\mathrm{ab}} \pm 1.36$ & $5.76^{\mathrm{abc}} \pm 0.50$ & $70.00^{\mathrm{ef}} \pm 2.64$ \\
\hline $1.00 \times 0.50$ & $7.20^{\mathrm{b}-\mathrm{e}} \pm 0.34$ & $1.83^{\mathrm{cd}} \pm 0.20$ & $0.70^{\mathrm{a}-\mathrm{d}} \pm 0.20$ & $9.33^{\mathrm{b}-\mathrm{f}} \pm 1.09$ & $4.73^{\mathrm{d}-\mathrm{f}} \pm 0.90$ & $76.60^{\mathrm{c}-\mathrm{e}} \pm 5.77$ \\
\hline $1.00 \times 1.00$ & $8.30^{\mathrm{ab}} \pm 1.21$ & $2.70^{\mathrm{a}} \pm 0.10$ & $0.63^{\mathrm{cd}} \pm 0.20$ & $8.90^{\text {def }} \pm 0.88$ & $6.50^{\mathrm{a}} \pm 0.20$ & $70.00^{\mathrm{ef}} \pm 5.00$ \\
\hline $1.00 \times 2.00$ & $7.20^{\mathrm{b}-\mathrm{e}} \pm 0.10$ & $1.93^{b c} \pm 0.20$ & $0.70^{\mathrm{a}-\mathrm{d}} \pm 0.10$ & $9.76^{\mathrm{b}-\mathrm{d}} \pm 0.66$ & $4.40^{\mathrm{e}-\mathrm{g}} \pm 0.52$ & $86.60^{\mathrm{ab}} \pm 7.02$ \\
\hline $2.00 \times 0.00$ & $9.60^{\mathrm{a}} \pm 1.22$ & $1.53^{\mathrm{ef}} \pm 0.05$ & $0.80^{\mathrm{a}-\mathrm{d}} \pm 0.20$ & $10.06^{\mathrm{bc}} \pm 0.85$ & $6.10^{\mathrm{a}} \pm 0.55$ & $90.00^{\mathrm{a}} \pm 5.00$ \\
\hline $2.00 \times 0.50$ & $8.10^{b c} \pm 0.80$ & $1.46^{\mathrm{f}} \pm 0.05$ & $0.40^{\mathrm{e}} \pm 0.10$ & $11.43^{\mathrm{a}} \pm 0.41$ & $4.46^{\mathrm{e}-\mathrm{g}} \pm 0.37$ & $83.30^{a-c} \pm 5.77$ \\
\hline $2.00 \times 1.00$ & $7.96^{\mathrm{bc}} \pm 0.70$ & $2.26^{\mathrm{ab}} \pm 0.11$ & $0.66^{\mathrm{bcd}} \pm 0.15$ & $10.06^{\mathrm{bc}} \pm 0.45$ & $4.93^{\mathrm{d}-\mathrm{f}} \pm 0.11$ & $73.30^{\mathrm{d}-\mathrm{f}} \pm 3.51$ \\
\hline $2.00 \times 2.00$ & $8.23^{b c} \pm 1.23$ & $1.40^{\mathrm{f}} \pm 0.10$ & $0.63^{\mathrm{cd}} \pm 0.05$ & $9.16^{\mathrm{c}-\mathrm{f}} \pm 1.25$ & $5.36^{\mathrm{a}}-\mathrm{d} \pm 0.41$ & $80.00^{b-d} \pm 0.00$ \\
\hline
\end{tabular}

Means with different letters on the same column are significantly different $(P<0.05)$ based on LSD test; mean \pm std. dev.

in the base of stem cuttings. IBA increases the concentration of endogenous auxins; the accumulation of IBA in the basal region of stem cuttings acts as a metabolizing agent and signal to produce roots (Husen, 2008). PGRs, especially IBA, change the metabolism of enzymes, carbohydrates, RNA, DNA and proteins (Dai et al., 2004; Husen and Pal, 2007; Brondani et al., 2012). IBA is the best auxin for general use because it is nontoxic to plants over a wide concentration range than other auxins; it is also effective in promoting the root formation of a large number of plant species (Hartmann et al., 2002).

In this study, various combinations of different concentrations of an auxin (IBA) and a cytokinin (KIN) were tested on rooting of semi-hard-wood cutting of $B$. hyrcana. The authors succeeded in inducing roots twice as much as possible ( 16.80 per cutting) by treating the cutting with $500 \mathrm{mg} / \mathrm{KIN}$ in combination with $1000 \mathrm{mg} / \mathrm{l}$ IBA, compared to the control. Moreover, the longest roots were observed in stem cuttings treated with $1000 \mathrm{mg} / \mathrm{l} \mathrm{KIN} \mathrm{in} \mathrm{combination} \mathrm{with} 1000 \mathrm{mg} / \mathrm{l} \mathrm{IBA}$. Contrary to author's finding, successful rooting without the application of auxin has been reported in a number of tropical tree species like Allanblackia floribunda (Atangana et al., 2006). Such contrasting results may be due to the variation in endogenous auxin contents in a particular species.

Auxin regulates various aspects of plant growth and development by affecting numerous processes including cell growth, development and differentiation (Husen et al., 2015). The different concentrations of IBA, NAA and cytokinins applied lead to a rooting response varied from species to species. In the present study, IBA in combination with KIN increased the rooting capacity of stem cuttings. Cuttings treated with median level of PGRs $(1000 \mathrm{mg} / \mathrm{l} \mathrm{IBA}$ in combination with $1000 \mathrm{mg} / \mathrm{l}$ KIN) produced more roots than other levels of IBA and KIN and untreated cuttings. The stimulatory effects of IBA in root induction of stem cuttings of several other woody plant species such as Dalbergia melanoxylon, Eucalyptus benthamii, Morus alba, and Macleania rupestris have been demonstrated by other researchers (Amri et al., 2010; Brondani et al., 2012; Veloza et al., 2014; Husen et al., 2015). The success of IBA may be due to 
its low activity and slow degradation by auxin degradation enzymes (Singh et al., 2014). However, high concentrations of auxin can cause damage to the base of the cutting. Auxin can be effective to rooting cuttings at a certain concentration, depending on the species and cultivar; on the other hand, it will have an inhibitive effect at higher concentrations (Galavi et al., 2013). Contrary to the authors' findings, Husen et al. (2015) and Singh et al. (2014) showed that a high concentration of IBA (3000 and $2000 \mathrm{mg} / \mathrm{l}$, respectively) was most effective for root production in terms of number and length in Morus alba L. Induction of more roots with higher IBA concentration has been reported in various plants such as Dalbergia melanoxylon, Vitis vinifera, Thuja compaecta and Macleania rupestris (Amri et al., 2010; Galavi et al., 2013; Singh et al., 2013; Veloza et al., 2014). Alizadeh and Grigorian (2002) demonstrated that the increase in NAA concentration from 1000 to $2000 \mathrm{mg} / \mathrm{l}$ increased rooting in semi-hardwood cuttings of almond-peach hybrid, whereas decrease in rooting was observed at concentration of $3000 \mathrm{mg} / \mathrm{l}$. Investigation of Shirzad et al. (2012) on Ficus benjamina revealed that the maximum root number and root length was obtained with 4000-6000 mg/l IBA. Sağlam et al. (2014) showed superiority of IAA than NAA and IBA for root induction and growth in Salvia fruticosa Mill. These researchers showed that the maximum root number values (77.40) were obtained in stem cuttings treated with $400 \mathrm{mg} / \mathrm{l}$ of IAA, NAA and IBA, respectively. In IBA application, especially at concentrations of 300 and $400 \mathrm{mg} / \mathrm{l}$, notable increases in root length were observed (Sağlam et al., 2014).

Present study showed the positive effect of KIN and IBA on shoot and leaf number, because the smallest number of shoots and leaves were produced in control plantlets. Maximum shoot and leaf number was obtained in cuttings treated with $1000 \mathrm{mg} / \mathrm{l} \mathrm{KIN}$ in combination with $2000 \mathrm{mg} / \mathrm{l} \mathrm{IBA}$. The author's work showed the synergic effect of KIN and IBA in terms of stimulating the production of highest shoot and leaf number. The investigation of Singh et al. (2014) on the rooting of stem cuttings of Morus alba L. demonstrated that the number of leaves per cutting was maximum in $2000 \mathrm{mg} / \mathrm{l}$ of IBA, followed by $1500 \mathrm{mg} / \mathrm{l}$ of IBA. The minimum number of leaves per cutting was calculated in control. Increase in leaf number may be due to vigorous rooting induced by the PGRs enabling the cuttings to absorb more nutrients and thereby produce more leaves (Stancato et al., 2003; Singh et al., 2014).

\section{In vitro propagation}

Management of tissue cultures of a particular species requires adequate knowledge concerning both its nutritional needs and the optimal combination of PGRs (Lucía et al., 2015). The choice of appropriate PGRs to induce shoot and leaf production is an essential process for in vitro propagation. The highest leaf induction was achieved using appropriate concentrations of both KIN and IBA. The explants treated with 1.00 and $2.00 \mathrm{mg} / \mathrm{l}$ KIN in combination with $1.00 \mathrm{mg} / \mathrm{l} \mathrm{IBA}$ promoted the longest leaves (over than $2 \mathrm{~cm}$ ). Moreover, $2.00 \mathrm{mg} / \mathrm{l}$ $\mathrm{KIN}$ in combination with $0.50 \mathrm{mg} / \mathrm{l} \mathrm{IBA}$ induced the formation of maximum leaf number with an average of 11.43. Leaves were also formed in a KIN- and IBA-free medium, but in lower numbers. Previous study on B. hyrcana (Kaviani and Negahdar, 2017) indicated that BAP alone was able to induce the maximum shoot number, but plantlets growth, node number, leaf number, root length, and root number could be increased when it was used in combination with NAA or IBA. Maximum number of leaves was observed in a medium fortified with $1.00 \mathrm{mg} / \mathrm{l} \mathrm{BAP}$ in combination with $1.50 \mathrm{mg} / \mathrm{l} \mathrm{IBA}$ (Kaviani and Negahdar, 2017). Optimum concentration for highest shoot multiplication was different among different plant species. This might be due to the content of endogenous PGRs in particular species. Moreover, the response to exogenous PGRs varies with plant species and the percentage of response varies with PGRs treatments and types of explants (Kaviani and Negahdar, 2017). The combination of cytokinins and different auxins did not improve shoot proliferation in some trees and shrubs species such as Vitis thunbergii, Prunus tomentosa and Prunus spp. (Lu, 2005; Pruski et al., 2005; Kalinina et al., 2007). These results are in contrast to our findings, in which the highest shoot proliferation was found in treatments containing KIN plus IBA. Similar results were reported by some researchers (Ďurkovič, 2008; Noroozi Sharaf et al., 2011). A study by Durkovič (2008) on Cornus mas, a shrub species showed that 0.70 $\mathrm{mg} / 1 \mathrm{BAP}$ in combination with $0.05 \mathrm{mg} / 1 \mathrm{NAA}$ was capable of stimulating continuous axillary and adventitious shoot proliferation. For Philodendron, the BA and KIN treatments showed a higher shoot formation percentage compared to the control (Chen et al., 2012). 
The results of the present study showed $100 \%$ of rooting on all the media tested (including the control) a month after the treatment. Maximum root number was produced in medium containing $1.00 \mathrm{mg} / \mathrm{l}$ of both KIN and IBA. Similar observation was made with $B$. hyrcana where explants cultured on MS medium supplemented with $0.50 \mathrm{mg} / 1 \mathrm{BAP}$ in combination with $1.00 \mathrm{mg} / 1 \mathrm{NAA}$ produced the largest number of roots (Kaviani and $\mathrm{Ne}$ gahdar, 2017). IBA is more effective for rooting as compared with other auxins as reported for many woody species (Onay, 2000; Kalinina et al., 2007). IBA and NAA promoted rooting of different trees and shrubs species (Takihira et al., 2007; Noroozi Sharaf et al., 2011; Chen et al., 2012). The current investigation revealed that explants cultured on medium fortified with $2.00 \mathrm{mg} / \mathrm{KIN}$ without IBA induced high root number and maximum root length. It is possible that, the content of auxins in the explants of $B$. hyrcana is adequate for root growth. The requirement of PGRs for shoot and root regeneration is species-specific. In the present study, all the plantlets were successfully acclimatized with a survival rate of $95 \%$.

\section{Conclusions}

B. hyrcana is in danger of extinction. Complementary in vivo and in vitro approaches represent important tools for ex situ conservation of plants germplasms particularly those threatened. The present study constitutes the second report on the propagation and micropropagation of $B$. hyrcana Pojark. Results in the current study demonstrated that the use of both KIN and IBA in appropriate concentrations induced higher rooting percentage and shoot proliferation in both propagation and micropropagation experiments. Following transfer to the adaptation greenhouse, $95 \%$ of the rooted shoots survived. The procedure presented in this study can be implemented for the mass production of $B$. hyrcana on a commercial scale.

\section{References}

Alizadeh A., Grigorian V. (2002) Rooting assessments of semi hardwood cuttings of almond - peach hybrid under mist conditions. Iranian J. Hort. Sci. Tech. 2(3): 143-154.

Al-Sagri F., Alderson P.G. (1996) Effect of IBA, cutting type and rooting media on rooting of Rosa centifolia. J. Hort. Sci. 71: 729-737.
Amri E., Lyaruu H.V.M., Nyomora A.S., Kanyeka Z.L. (2010) Vegetative propagation of African Blackwood (Dalbergia melanoxylon Guill. \& Perr.): Effects of age of donor plant, IBA treatment and cutting position on rooting ability of stem cuttings. New For. 39: 183-194.

Atangana A.R., Tchoundjeu Z., Asaah E.K., Simons A.J., Khasa D.P. (2006) Domestication of Allanblackia floribunda: amenability to vegetative propagation. For. Ecol. Manag. 237: 246-251.

Brickell C., Zuk J.D. (1996) A-Z Encyclopedia of garden plants. The American Horticultural Society. DK Publishing, Inc. New York, USA: 199.

Brondani G.E., Baccarin F.J.B., de Wit Ondas H.W., Stape J.L., Gonçalves A.N., de Almeida M. (2012) Low temperature, IBA concentrations and optimal time for adventitious rooting of Eucalyptus benthamii mini-cuttings. J. For. Res. 23(4): 583-592.

Chen F.C., Wangb C.Y., Fang J.Y. (2012) Micropropagation of self-heading Philodendron via direct shoot regeneration. Sci. Hort. 141: 23-29.

Corrêa L.R., Fett-Neto A.G. (2004) Effects of temperature on adventitious root development in microcuttings of Eucalyptus saligna Smith and Eucalyptus globulus Labill. J. Therm. Biol. 29(6): 315-324.

Dai W., Cheng Z.M., Sargent W.A. (2004) Expression of the rolB gene enhances adventitious root formation in hardwood cuttings of aspen. In Vitro Cell. Dev. Biol. - Plant. 40(4): 366-370.

Davidović V., Popović R., Radulović M. (2015) Influence of IBA and NAA (0.8\%) + (IBA 0.5\%) phytoregulators to the rizhogenesis of the mature lemon tree-shoots (Citrus limon (L.) Burm. and Citrus meyearii Y. Tan.). Agric. For. 61(2): 243-250.

de Oliveira A.P., Nienow A., y Calvete A., de Oliveira E. (2003) Rooting potential capacity of peach tree cultivars of semihardwood and hardwood cuttings treated with IBA. Rev. Bras. Frutic. 25: 282-285.

Durkovič J. (2008) Micropropagation of mature Cornus mas 'Macrocarpa'. Trees. 22: 597-602.

Galavi M., Karimian M.A., Mousavi S.R. (2013) Effects of different auxin (IBA) concentrations and planting-beds on rooting grape cuttings (Vitis vinifera). Ann. Rev. Res. Biol. 3(4): 517-523.

Hartmann H.T., Kester D.E., Davies F.T., Geneve R.L. (1997) Plant propagation: principles and practices. 6th edition, Prentice-Hall, Inc., Englewood Cliffs, New Jersey.

Hartmann H.T., Kester D.E., Davies F.T., Geneve R.L. (2002) Plant propagation: principles and practices. $7^{\text {th }}$ edition, Prentice Hall, Inc., Upper Saddle River: 176-328.

Hartmann H.T., Kester D.E., Davies J.R.F.T., Geneve R.L. (2011) Plant propagation: principles and practices. $8^{\text {th }}$ edition, Prentice-Hall, São Paulo: 915.

Hunt M.A., Trueman S.J., Rasmussen A. (2011) Indole-3-butyric acid accelerates adventitious root formation and impedes shoot growth of Pinus elliottii var. elliottii $\times$ P. carIBAea var. hondurensis cuttings. New For. 41(3): 349-360. 
Husen A., Iqbal M., Siddiqui S.N., Sohrab S.S., Masresha G. (2015) Effect of indole-3-butyric acid on clonal propagation of mulberry (Morus alba L.) stem cuttings: rooting and associated biochemical changes. Proc. Natl. Acad. Sci., Sect. B, Biol. Sci., India.

Husen A., Pal M. (2007) Metabolic changes during adventitious root primordium development in Tectona grandis Linn. f. (teak) cuttings as affected by age of donor plants and auxin (IBA and NAA) treatment. New For. 33 (3): $309-323$.

Husen A. (2008) Clonal propagation of Dalbergia sissoo Roxb. and associated metabolic changes during adventitious root primordium development. New For. 36(1): 13-27.

Kalinina A., Daniel C., Brown W. (2007) Micropropagation of ornamental Prunus spp. and GF305 peach, a Prunus viral indicator. Plant Cell Rep. 26: 927-935.

Kaviani B., Negahdar N. (2017) Propagation, micropropagation and cryopreservation of Buxus hyrcana Pojark., an endangered ornamental shrub. South Afr. J. Bot. 111: 326-335.

Kesari V., Krishnamachari A., Rangan L. (2009) Effect of auxins on adventitious rooting from stem cuttings of candidate plus tree Pongamia pinnata (L.), a potential biodiesel plant. Trees. 23: 597-604.

Lu M.C. (2005) Micropropagation of Vitis thunbergii Sieb. et Zucc., a medicinal herb, through high-frequency shoot tip culture. Sci. Hort. 107: 64-69.

Lucía G.R., Jesicad I., Andreaa C., Verónicab B., Paulaa B., Sandrac P.Á., Alejandrod E. (2015) A protocol for the in vitro propagation and polyploidization of aninterspecific hybrid of Glandularia ( $G$. peruviana $\times$ G. scrobiculata). Sci. Hort. 184: 46-54.

Mahendran G., Bai V.N. (2009) Mass propagation of Satyrium nepalense D.Don. - A medicinal orchid via seed culture. Sci. Hort. 119: 203-207.

Murashige T., Skoog F. (1962) A revised medium for rapid growth and bioassays with tobacco tissue cultures. Physiol. Plant. 15: 473-479.

Noroozi Sharaf A.R., Hamidoghli Y., Zakizadeh H. (2011) In vitro seed germination and micropropagation of primrose (Primula heterochroma Stapf.) an endemic endangered Iranian species via shoot tip explants. Hort. Environ. Biotechnol. 52(3): 298-302.

Onay A. (2000) Micropropagation of Pistachio from mature trees. Plant Cell Tiss. Org. Cult. 60: 159-162.

Poston A.L. (2007) Cutting propagation and container production of Rudy Haag burning bush [Euonymus alatus Rudy Haag]. M.Sc. Thesis, University of Kentucky.
Pruski K.W., Astatkie T., Nowak J. (2005) Tissue culture propagation of Mongolian cherry (Prunus fruticosa) and Nanking cherry (Prunus tomentosa). Plant Cell Tiss. Org. Cult. 82: 207-211.

Sağlam A.C., Yaver S., Başer İ., Cínkiliç L. (2014) The effects of different hormones and their doses on rooting of stem cuttings in anatolian sage (Salvia fruticosa Mill.). APCBEE Procedia. 8: 348-353.

Shirzad M., Sedaghathoor Sh., Hashemabadi D. (2012) Effect of media and different concentrations of IBA on rooting of "Ficus benjamina L." cutting. J. Ornamen. Hortic. Plants. 2(1): 61-64.

Singh K.K., Choudhary T., Kumar A. (2014) Effect of various concentrations of IBA and NAA on the rooting of stem cuttings of mulberry (Morus Alba L.) under mist house condition in Garhwal Hill region. Ind. J. Hill Farm. 27(1): 74-77.

Singh K.K., Rawat J.M.S., Tomar Y.K., Kumar P. (2013) Effect of IBA concentration on inducing rooting in stem cuttings of Thuja compecta under mist house condition. Hort. Flora Res. Spectrum. 2(1): 30-34.

Stancato G.C., Aguiar F.F.A., Kanashiro S., Tavares A.R. (2003) Rhipsali grandiflora Haw. propagation by stem cuttings. Sci. Agricola. 56: 185-190.

Takihira M., Otani M., Tsuchiya S., Shimada T. (2007) Plant regeneration from leaf explants of auricula cultivars (Primula $\times$ pubescens Jacq.). Plant Biotech. 24: 425-427.

Tchoundjeu Z., Mpeck M.L., Asaah E., Amougou A. (2004) The role of vegetative propagation in the domestication of Pausinystalia johimbe K. Schum, a highly threatened medicinal species of West and Central Africa. For. Ecol. Manag. 188: $175-183$.

Tsipouridis C., Thomidis T., Isaakidis A. (2003) Rooting of peach hardwood and semi-hardwood cuttings. Aust. J. Exp. Agric. 43: 1363-1368.

Veloza C., Duran S., Magnitskiy S., Lancheros H. (2014) Rooting ability of stem cuttings of Macleania rupestris Kunth A.C. Sm., a South American fruit species. Int. J. Fruit Sci. 14: 343-361.

Wendling I., Brondani G.E., Dutra L.F., Hansel F.A. (2010) Mini-cuttings technique: A new ex vitro method for clonal propagation of sweetgum. New For. 39 (3): 343-353.

Zhu X.Y., Chai S.J., Chen L.P., Zhang M.F., Yu J.Q. (2010) Induction and origin of adventitious roots from chimeras of Brassica juncea and Brassica oleracea. Plant Cell Tiss. Org. Cult. 101 (3): 287-294. 